\title{
GM1 gangliosidosis type 2
}

INSERM

\section{Source}

INSERM. (1999). Orphanet: an online rare disease and orphan drug data base. GM1 gangliosidosis type 2. ORPHA:79256

GM1 gang liosidosis type 2 is a clinically variable, infancy or childhood-onset form of GM1 gang liosidosis (see this term) characterized by normal early development and psychomotor regression between seven months and three years of age. 